\title{
BUDIDAYA TANAMAN BAWANG MERAH
}

Oleh:

Nama : Akira Tabuni. Nim : 1754211001.

Dosen Pegampuh : Mahrus Ali S.Tp. M.Agr

FAKULTAS PERTANIAN

PROGRAM STUDI AGROTEKNOLOGI

UNIVERSITAS MERDEKA SURABAYA

TAHUN 2017

\begin{abstract}
ABSTRAK
Bawang Merah Atau Brambang (Allium Ascalonicum L.) Adalah Nama Tanaman Dari Familia Alliaceae Dan Nama Dari Umbi Yang Dihasilkan. Umbi Dari Tanaman Bawang Merah Merupakan Bahan Utama Untuk Bumbu Dasar Masakan Indonesia. Bawang Merah Menyukai Daerah Yang Beriklim Kering Dengan Suhu Agak Panas Dan Mendapat Sinar Matahari Lebih Dari 12 Jam. Bawang Merah Dapat Tumbuh Baik Didataran Rendah Maupun Dataran Tinggi (0-900 Mdpl) Dengan Curah Hujan 300 - 2500 Mm/Th Dan Suhunya 25 Derajat Celcius - 32 Derajat Celcius. Jenis Tanah Yang Baik Untuk Budidaya Bawang Merah Adalah Regosol, Grumosol, Latosol, Dan Aluvial, Dengan Ph 5.5 - 7. Untuk Budidaya Bawang Merah, Pengolahan Tanah Dilakukan Pada Saat Tidak Hujan 2 - 4 Minggu Sebelum Tanam, Untuk Menggemburkan Tanah Dan Memberik Sirkulasi Udara Dalam Tanah. Tanah Dicangkul Sedalam $40 \mathrm{Cm}$. Budidaya Dilakukan Pada Bedengan Yang Telah Disiapkan Dengan Lebar 100-200 Cm, Dan Panjang Sesuai Kebutuhan. Jarak Antara Bedengan 20-40 Cm. Penanaman Dilakukan Pada Akhir Musim Hujan, Dengan Jarak Tanam 10-20 Cm X 20 Cm. Cara Penanamannya; Kulit Pembalut Umbi Dikupas Terlebih Dahulu Dan Dipisahkan Siung-Siungnya. Untuk Mempercepat Keluarnya Tunas, Sebelum Ditanam Bibit Tersebut Dipotong Ujungnya Hingga 1/3 Bagian. Bibit Ditanam Berdiri Diatas Bedengan Sampai Permukaan Irisan Tertutup Oleh Lapisan Tanah Yang Tipis. Pemeliharaan Dilakukan Dengan Penyiraman Dengan Menggunakan Gembor Atau Sprinkler, Atau Dengan Cara Menggenangi Air Disekitar Bedengan Yang Disebut Sistem Leb. Pengairan Dilakukan Secara Teratur Sesuai Dengan Keperluan Tanaman, Terutama Jika Tidak Ada Hujan.
\end{abstract}

Kata Kunci: Bawang Merah, Teknik Budidaya,

\section{PENDAHULUAN}

\section{A. Latar Belakang}

Bawang Merah (Allium Ascalonicum L) Family Lilyceae Yang Berasalz Dari Asia Tengah Merupakan Salah Satu Komoditas Hortikultura Yang Sering Digunakan Sebagai Penyedap Masakan. Selain Itu, Bawang Merah Juga Mengandung Gizi Dan Senyawa Yang Tergolong Zat Non Gizi Serta Enzim Yang Bermanfaat Untuk Terapi, Serta Meningkatkan 
Dan Mempertahankan Kesehatan Tubuh Manusia. Kebutuhan Bawang Merah Di Indonesia Dari Tahun Ke Tahun Mengalami Peningkatan Sebesar 5\%. Hal Ini Sejalan Dengan Bertambahnya Jumlah Populasi Indonesia Yang Setiap Tahunnya Juga Mengalami Peningkatan.

Badan Pusat Statistik (BPS) Dan Direktorat Jenderal Holtikultura (DJH) Menyebutkan Bahwa Produksi Bawang Merah Di Indonesia Dari Tahun 2006-2010 Selalu Mengalami Peningkatan Yaitu Sebesar 794.929 Ton, 802.810 Ton, 853.615 Ton, 965.164 Ton, 1.048.934 Ton. Akan Tetapi, Sepanjang Tahun 2010 Impor Bawang Merah Di Indonesia Tercatat Sebesar 73.864 Ton Dan Dalam Tiga Bulan Pertama Tahun 2011, Impor Bawang Merah Di Indonesia Mencapai 85.730 Ton. Hal Itu Membuktikan Bahwa Kebutuhan Akan Bawang Merah Di Dalam Negeri Masih Tinggi Dibandingkan Ketersediaannya. Dengan Demikian, Produktivitas Bawang Merah dalam Negeri Perlu Ditingkatkan. Bertambahnya Penduduk Menyebabkan Kebutuhan Bawang Merah Mengalami Peningkatan. Sedangkan Lahan Yang Tersedia Semakin Sempit.

Sehingga Dibutuhkan Upaya Untuk Meningkatkan Hasil Produksi Pangan Dengan Cara Pemberian Perlakuan Yang Menggunakan Bunyi Pada Peak Frekuensi Tertentu Pada Tanaman. Getaran Bunyi Dapat Mempengaruhi Pembukaan Stomata Daun Menjadi Lebih Lebar (Goenadi Dan Mashuri, 2002: 89), Sehingga Dapat Mempengaruhi Pertumbuhan Tanaman Dan Meningkatkan Produktivitas Tanaman. Oleh Karena itu, Ingin Membuktikan Apakah Ada Pengaruh Frekuensi Bunyi Terhadap Pembukaan Stomata Daun, Pertumbuhan Dan Produktivitas Tanaman [1]. Tanaman Bawang Merah (Allium Ascalonicum L) Dan Sumber Bunyi Yang Digunakan Adalah Suara "Jangkrik" (Gryllidae) Termanipulasi Pada Peak Frequency $(4,43 \pm 0,05) 103$ Hz. Jangkrik Banyak Ditemukan Di Daerah Lahan Pertanian Dan Ketika Jangkrik Berbunyi Di Lahan Pertanian, Maka Serangga-Serangga Pada Umumnya Akan Keluar Dan Ikut Berbunyi.

Adapun Faktor Lain Yang Mempengaruhi Pertumbuhan Dan Produktivitas Tanaman Seperti Jenis Tanah, Kelembaban Udara, Ph Tanah, Persediaan Air, Cahaya Matahari, Perawatan, Pemberian Pupuk Dan Obat-Obatan, Serta Pengendalian Hama Dan Penyakit Pada Tanaman [2]. Pengaruh Pemaparan Bunyi Jangkrik Termanipulasi Pada Peak Frequency $(4,43 \pm 0,05) 103$ Hz Terhadap Pertumbuhan Dan Produktivitas Bawang Merah.

\section{B. Tujuan}

1. Mengamati Pengaruh Pemaparan Bunyi "Jangkrik" Termanipulasi Pada Peak Frequency $(4,43 \pm 0,05) 103$ Hz Terhadap Pembukaan Stomata Daun Bawang Merah. 
2. Mengetahui Perbedaan Pertumbuhan Bawang Merah Tanaman Perlakuan Pada Peak Frequency $(4,43 \pm 0,05) 103 \mathrm{~Hz}$ Dengan Tanaman Kontrol.

3. Mengetahui Peningkatan Hasil Panen Tanaman Bawang Merah Yang Diberi Perlakuan Bunyi Dengan Tanaman Bawang Merah Yang Tidak Diberi Perlakuan Bunyi (Kontrol).

\section{Manfaat}

1. Dapat Mengetahui Pengaruh Pemaparan Bunyi "Jangkrik" Termanipulasi Pada Peak Frequency $(4,43 \pm 0,05) 103 \mathrm{~Hz}$ Terhadap Laju Pertumbuhan Bawang Merah Serta Mengetahui Perbedaan Antara Bawang Merah (Allium Ascalonicum L) Yang Diberi Perlakuan Bunyi Dengan Bawang Merah (Allium Ascalonicum L) Yang Tidak Diberi Perlakuan Bunyi (Tanaman Kontrol).

2. Dapat Mengetahui Pengaruh Pemaparan Bunyi "Jangkrik" Termanipulasi Pada Peak Frequency $(4,43 \pm 0,05) 103 \mathrm{~Hz}$ Terhadap Pembukaan Stomata Daun Pada Bawang Merah (Allium Ascalonicum L).

3. Dapat Dimanfaatkan Oleh Para Petani Sebagai Salah Satu Cara Untuk Meningkatkan Produktivitas Tanaman Bawang Merah (Allium Ascalonicum L) Di Indonesia.

4. Dapat Menambah Pengetahuan Para Mahasiswa Tentang Ilmu Fisika Yang Berkaitan Dengan Ilmu Biologi, Terutama Mengenai Pengaruh Gelombang Bunyi Terhadap Tanaman. Hal Ini Menunjukkan Bahwa Ilmu Fisika Dapat Diaplikasikan Dalam Kehidupan Sehari-Hari Sebagai Ilmu Yang Bermanfaat Bagi

Masyarakat.

Bawang Merah Merupakan Salah Satu Komoditas Sayuran Unggulan Yang Sejak Lama Telah Diusahakan Oleh Petani Secara Intensif. Komoditas Sayuran Ini Termasuk Ke Dalam Kelompok Rempah Tidak Bersubstitusi Yang Berfungsi Sebagai Bumbu Penyedap Makanan Serta Bahan Obat Tradisional.

Bawang Merah ( Allium Ascalonicum) Merupakan Komoditas Hortikultura Yang Memiliki Banyak Manfaat Dan Bernilai Ekonomis Tinggi Serta Mempunyai Prospek Pasar Yang Menarik. Selama Ini Budidaya Bawang Merah Diusahakan Secara Musiman (Seasonal), Yang Pada Umumnya Dilakukan Pada Musim Kemarau (April-Oktober), Sehingga Mengakakibatkan Produksi Dan Harganya Berfluktuasi Sepanjang Tahun.

Untuk Mencegah Terjadinya Fluktuasi Produksi Dan Fluktuasi Harga Yang Sering Merugikan Petani, Maka Perlu Diupayakan Budidaya Yang Dapat Berlangsung Sepanjang Tahun Antara Lain Melalui Budidaya Di Luar Musim (Off Season). Dengan Melakukan Budidaya Di Luar Musim Dan Membatasi Produksi Pada Saat Bertanam Normal Sesuai 
Dengan Permintaan Pasar, Diharapkan Produksi Dan Harga Bawang Merah Dipasar Akan Lebih Stabil.

\section{PEMBAHASAN}

A. Pengertian Bwang Merah

Bawang Merah Atau Brambang (Allium Ascalonicum L.) Adalah Nama Tanaman Dari Familia Alliaceae Dan Nama Dari Umbi Yang Dihasilkan. Umbi Dari Tanaman Bawang Merah Merupakan Bahan Utama Untuk Bumbu Dasar Masakan Indonesia. Bawang Merah Merupakan Bagian Penting Dari Bumbu Masakan, Baik Untuk Masakan Rumah Tangga, Restoran Maupun Industri Makanan, Di Samping Itu Bawang Merah Juga Bisa Di Manfaatkan Sebagai Obat Herbal. Bawang Merah Memiliki Nama Lokal Di Antaranya: Bawang Abang Mirah (Aceh), Bawang Abang (Palembang), Dasun Merah (Minangkabau), Bawang Suluh (Lampung), Bawang Beureum (Sunda), Brambang Abang (Jawa), Bhabang Merah (Madura), Dan Masih Banyak Lagi Yang Lainnya, Masing-Masing Daerah Memiliki Sebutan Tersendiri.

Bawang Merah Adalah Tanaman Semusim Dan Memiliki Umbi Yang Berlapis. Tanaman Mempunyai Akar Serabut, Dengan Daun Berbentuk Silinder Berongga. Umbi Terbentuk Dari Pangkal Daun Yang Bersatu Dan Membentuk Batang Yang Berubah Bentuk Dan Fungsi, Membesar Dan Membentuk Umbi Berlapis. Umbi Bawang Merah Terbentuk Dari Lapisan-Lapisan Daun Yang Membesar Dan Bersatu. Umbi Bawang Merah Bukan Merupakan Umbi Sejati Seperti Kentang Atau Talas.

Bawang Goreng Adalah Bawang Merah Yang Diiris Tipis Dan Digoreng Dengan Minyak Goreng Yang Banyak. Pada Umumnya, Masakan Indonesia Berupa Soto Dan Sup Menggunakan Bawang Goreng Sebagai Penyedap Sewaktu Dihidangka.Bawang Goreng Merupakan Bumbu Yang Paling Sering Di Gunakan Orang Indonesia Untuk Membuat Masakan.

Umbi Bawang Merah Dan Bawang Bombay Dikenal Dapat Menginduksi Keluarnya Air Mata Apabila Diiris. Hal Ini Disebabkan Reaksi Berantai Yang Terjadi Dalam Sel-Sel Umbinya. Apabila Umbi Lapis Diiris, Sel-Selnya Akan Pecah Dan Melepaskan Berbagai Senyawa Yang Terkandung Di Dalamnya. Dua Senyawa Yang Terlepas Di Antaranya Adalah Enzim Allinase And Asam Amino. Allinase Yang Bertemu Dengan Asam Amino Yang Mengandung Belerang (Sulfoksida, Yaitu Sistein Dan Metionin) Akan Melepaskan Asam Sulfenat (R-Soh). Asam Sulfenat Bersifat Tidak Stabil Dan Segera Berubah Menjadi Tiosulfinat [R-S(O)-S-R']. Tiosulfinatlah Yang Bertanggung Jawab Atas Aroma Khas 
Bawang. Selain Menjadi Tiosulfinat, Asam Sulfenat Yang Bertemu Dengan Enzim Lain, LfSintase (Lf Singkatan Dari Lacrymatory Factor: "Faktor Air Mata"), Akan Diubah Menjadi Syn-Propanethial-S-Oxide Yang Berwujud Gas. Apabila Gas Ini Mengenai Kornea Mata, Signal Dikirim Sebagai Gangguan Pada Mata Dan Mata Akan Berkedip-Kedip Serta Mengeluarkan Air Mata Untuk "Mengusir" Pengganggu Ini.

B. Syarat Tumbuh

Bawang Merah Menyukai Daerah Yang Beriklim Kering Dengan Suhu Agak Panas Dan Mendapat Sinar Matahari Lebih Dari 12 Jam. Bawang Merah Dapat Tumbuh Baik Didataran Rendah Maupun Dataran Tinggi (0-900 Mdpl) Dengan Curah Hujan 300 - 2500 Mm/Th Dan Suhunya 25 Derajat Celcius - 32 Derajat Celcius. Jenis Tanah Yang Baik Untuk Budidaya Bawang Merah Adalah Regosol, Grumosol, Latosol, Dan Aluvial, Dengan Ph 5.57. C. Benih

Penggunaan Benih Bermutu Merupakan Syarat Mutlak Dalam Budidaya Bawang Merah. Varietas Bawang Merah Yang Dapat Digunakan Adalah Bima, Brebes, Ampenan, Medan, Keling, Maja Cipanas, Sumenep, Kuning, Timor, Lampung, Banteng Dan Varietas Lokal Lainnya. Tanaman Biasanya Dipanen Cukup Tua Antara 60 -80 Hari, Telah Diseleksi Dilapangan Dan Ditempat Penyimpanan. Umbi Yang Digunakan Untuk Benih Adalah Berukuran Sedang, Berdiameter 1,5 - 2 Cm Dengan Bentuk Simetris Dan Telah Disimpan 24 Bulan, Warna Umbi Untuk Lebih Mengkilap, Bebas Dari Organisme Penganggu Tanaman.

D. Penyiapan Lahan

Pengolahan Tanah Dilakukan Pada Saat Tidak Hujan 2 - 4 Minggu Sebelum Tanam, Untuk Menggemburkan Tanah Dan Memberik Sirkulasi Udara Dalam Tanah. Tanah Dicangkul Sedalam $40 \mathrm{Cm}$. Budidaya Dilakukan Pada Bedengan Yang Telah Disiapkan Dengan Lebar 100-200 Cm, Dan Panjang Sesuai Kebutuhan. Jarak Antara Bedengan 20-40 $\mathrm{Cm}$.

E. Penanaman

Penanaman Dilakukan Pada Akhir Musim Hujan, Dengan Jarak Tanam 10-20 Cm X 20 Cm. Cara Penanamannya; Kulit Pembalut Umbi Dikupas Terlebih Dahulu Dan Dipisahkan Siung-Siungnya. Untuk Mempercepat Keluarnya Tunas, Sebelum Ditanam Bibit Tersebut Dipotong Ujungnya Hingga 1/3 Bagian. Bibit Ditanam Berdiri Diatas Bedengan Sampai Permukaan Irisan Tertutup Oleh Lapisan Tanah Yang Tipis.

F. Pemeliharaan

1. Penyiraman Dapat Menggunakan Gembor Atau Sprinkler, Atau Dengan Cara Menggenangi Air Disekitar Bedengan Yang Disebut Sistem Leb. Pengairan 
Dilakukan Secara Teratur Sesuai Dengan Keperluan Tanaman, Terutama Jika Tidak Ada Hujan.

2. Pemupukan : Pupuk Yang Diberikan Adalah Pupuk Kandang, Dengan Dosis 10 Ton/Ha, Pupuk Buatan Dengan Dosis Urea 100 Kg/Ha, ZA 200 Kg/Ha, TSP/SP-36 $250 \mathrm{Kg} / \mathrm{Ha}$. KCI $150 \mathrm{Kg} / \mathrm{Ha}$ (Sesuai Dengan Kesuburan Tanah).

3. Penyulaman, Dilakukan Apabila Dilapangan Dijumpai Tanaman Yang Mati. Biasanya Dilakukan Paling Lambat 2 Minggu Setelah Tanam.

4. Pembumbunan Dan Penyiangan, Dilakukan Bersamaan Pada Saat Tanaman Berumur 21 Hari.

5. Pengendalian OPT Dilakukan Tergantung Pada Serangan Hama Dan Penyakit. Hama Yang Menyerah Tanaman Bawang Merah Adalah Ulat Tanah, Ulat Daun, Ulat Grayak, Kutu Daun Dan Nematoda Akar.

Pengendalian Hama Dilakukan Dengan Cara:

1. Sanitasi Dan Pembuangan Gulma

2. Pengumpulan Larva Dan Memusnahkan

3. Pengolahan Lahan Untuk Membongkar Persembunyian Ulat

4. Penggunaan Insektisida

5. Rotasi Tanaman

Penyakit Yang Sering Menyerang Bawang Merah Adalh Bercak Ungu, Embun Tepung, Busuk Leher Batang, Antraknose, Busuk Umbi, Layu Fusarium Dan Busuk Basah. Pengendalian Penyakit Dilakukan Dengan Cara:

1. Sanitasi Dan Pembakaran Sisa Tanaman Yang Sakit

2. Penggunaan Benih Yang Sehat.

3. Penggunaan Fungisida Yang Efekti

G. Panen dan Pasca Panen

1. Panen Dilakukan Bila Umbi Sudah Cukup Umur Sekitar 60 HST, Ditandai Daun Mulai Menguning, Caranya Mencabut Seluruh Tanaman Dengan Hati-Hati Supaya Tidak Ada Umbi Yang Tertinggal Atau Lecet. Untuk 1 (Satu) Hektar Pertanaman Bawang Merah Yang Diusahakan Secara Baik Dapat Dihasilkan 10-15 Ton. Pengeringan Umbi Dilakukan Dengan Cara Dihamparkan Merata Diatas Tikar Atau

2. Digantung Diatas Para-Para. Dalam Keadaan Cukup Panas Biasanya Memakan Waktu 4-7 Hari. Bawang Merah Yang Sudah Agak Kering Diikat Dalam Bentuk Ikatan.Proses Pengeringan Dihentikan Apabila Umbi Telah Mengkilap, Lebih Merah, Leher Umbi Tampak Keras Dan Bila Terkena Sentuhan Terdengar Gemerisik. 
3. Sortasi Dilakukan Setalh Proses Pengeringan.

4. Ikatan Bawang Merah Dapat Disimpan Dalam Rak Penyimpanan Atau Digantung Dengan Kadar Air 80 (Persen) - 85 (Persen), Ruang Penyimpnan Harus Bersih, Aerasi Cukup Baik, Dan Harus Khusus Tidak Dicampur Dengan Komoditas Lain.

\section{KESIMPULAN}

Bawang Merah Atau Brambang (Allium Ascalonicum L.) Adalah Nama Tanaman Dari Familia Alliaceae Dan Nama Dari Umbi Yang Dihasilkan. Umbi Dari Tanaman Bawang Merah Merupakan Bahan Utama Untuk Bumbu Dasar Masakan Indonesia. Bawang Merah Menyukai Daerah Yang Beriklim Kering Dengan Suhu Agak Panas Dan Mendapat Sinar Matahari Lebih Dari 12 Jam. Bawang Merah Dapat Tumbuh Baik Didataran Rendah Maupun Dataran Tinggi (0-900 Mdpl) Dengan Curah Hujan 300 - 2500 Mm/Th Dan Suhunya 25 Derajat Celcius - 32 Derajat Celcius. Jenis Tanah Yang Baik Untuk Budidaya Bawang Merah Adalah Regosol, Grumosol, Latosol, Dan Aluvial, Dengan Ph 5.5 - 7.

Untuk Budidaya Bawang Merah, Pengolahan Tanah Dilakukan Pada Saat Tidak Hujan 2 - 4 Minggu Sebelum Tanam, Untuk Menggemburkan Tanah Dan Memberik Sirkulasi Udara Dalam Tanah. Tanah Dicangkul Sedalam 40 Cm. Budidaya Dilakukan Pada Bedengan Yang Telah Disiapkan Dengan Lebar 100-200 Cm, Dan Panjang Sesuai Kebutuhan. Jarak Antara Bedengan 20-40 Cm. Penanaman Dilakukan Pada Akhir Musim Hujan, Dengan Jarak Tanam 10-20 Cm X 20 Cm. Cara Penanamannya; Kulit Pembalut Umbi Dikupas Terlebih Dahulu Dan Dipisahkan Siung-Siungnya. Untuk Mempercepat Keluarnya Tunas, Sebelum Ditanam Bibit Tersebut Dipotong Ujungnya Hingga 1/3 Bagian. Bibit Ditanam Berdiri Diatas Bedengan Sampai Permukaan Irisan Tertutup Oleh Lapisan Tanah Yang Tipis. Pemeliharaan Dilakukan Dengan Penyiraman Dengan Menggunakan Gembor Atau Sprinkler, Atau Dengan Cara Menggenangi Air Disekitar Bedengan Yang Disebut Sistem Leb. Pengairan Dilakukan Secara Teratur Sesuai Dengan Keperluan Tanaman, Terutama Jika Tidak Ada Hujan.

\section{REFERENCE}

Aak, 2004. Pedoman Bertanam Bawang, Kanisius, Yogyakarta. Hlm 18. BPPT, 2007. Teknologi Budidaya Tanaman Pangan.

[1] B. W. Hariyadi, M. Ali, and N. Nurlina, "Damage Status Assessment Of Agricultural Land As A Result Of Biomass Production In Probolinggo Regency East Java," ADRI Int. J. Agric., vol. 1, no. 1, 2017. 

KANDUNGAN CAPSAICIN PADA BUAH TANAMAN CABE RAWIT (Capsicum frutescens L.)," J. AGROSAINS KARYA Kreat. DAN Inov., vol. 2, no. 2, pp. 171-178, 2015.

Deptan. 2007 . Pengenalan Dan Pengendalian Beberapa OPT Benih Hortikultura. , 2007 . Prospek Dan Arah Pengembangan Agribisnis Bawang Merah.

Irwan, 2007. Bawang Merah Dan Pestisida.

Moekesan.T.K., Prabaningrum, L., Dan Meitha, L.R., 2000. Penerapan PHT. Pada System Tanaman Tumpang Gilir. Bawang Merah Dan Cabai.. Balai Penelitian Tanaman Sayuran Pusat Penelitian Dan Pengembangan Hortikultura Badan Penelitian Dan Pengembangan Pertanian, Jakarta Hlm 8-10, 30.

Rukmana, R, 1995. Bawang Merah Budidaya Dan Pengolahan Pasca Panen. Kanisius, Jakarta, Hlm 18.

Rahayu, E, Dan Berlian,N. V. A, 1999. Bawang Merah. Penebar Swadaya, Jakarta, Hlm4.

Suhardi, 1998. Jurnal Hortikultura, Badan Penelitian Dan Pengembangan Hortikultura, Jakarta. Hlm. 1021.

Semangun, H, 2000. Penyakit-Penyakit Tanaman Hortikultura Di Indonesia. Gadjah Mada University Press Yogyakarta. Hlm. 23-27.

Wibowo, S, 1994. Budidaya Bawang Putih, Bawang Merah, Bawang Bombay. Penebar Swadaya, Jakarta. Hlm. 179. 